\title{
ANALISIS PENGARUH RETURN ON ASSET, CAPITAL ADEQUACY RATIO, LOAN TO DEPOSIT RATIO TERHADAP TINGKAT KREDIT MACET PADA PERUSAHAAN PERBANKAN BUMN TAHUN 2017-2019
}

\section{Thesya Yuzevin}

Fakultas Ekonomi, Universitas Tidar, Magelang

thesyayuzevin@gmail.com

\section{Yacobo P. Sijabat}

Fakultas Ekonomi, Universitas Tidar, Magelang

yacobo.djabat@untidar.ac.id

\begin{abstract}
Banks are briefly defined as business entities that collect funds from the public and channel them back to the public in the form of credit or other forms, which are one of the influential sectors in a country's economy. Channeling funds to the public or also called credit (leasing) aims to help improve the lives of many people. The existence of this loan often faces problems, namely non-performing loans (NPLS) where there are credit risks faced by the Bank due to the inability of the customer or debtor to return the amount of loans received from the Bank along with interest within a predetermined period of time. This study aims to determine the effect of Return On Assets (ROA), Capital Adequacy Ratio (CAR), Loan To Deposit Ratio (LDR) on the level of non-performing loans (NPLS) in SOE banking companies in 2017-2019. The research method used is descriptive quantitative by using combined panel data from cross sections and time series using SOE Bank financial report data for the 2017-2019 period. The results of this study indicate the influence of ROA on NPL, while CAR and LDR do not have a significant effect that indicates good company performance.
\end{abstract}

Keywords: Bank, NPL, ROA, CAR, LDR

\section{PENDAHULUAN}

Dalam kehidupan sehari-hari, bank merupakan suatu lembaga keuangan yang dibutuhkan oleh masyarakat. Secara singkat bank diartikan sebagai badan usaha yang menghimpun dana dari masyarakat dan menyalurkannya kembali kepada masyarakat dalam bentuk pinjaman kredit atau bentuk lainnya. Menghimpun dana atau dalam dunia perbankan di sebut funding dijelaskan sebagai mencari atau mengumpulkan dana dengan cara membeli dana dari masyarakat dan memasang berbagai strategi berupa balas jasa (bunga, bagi hasil, hadiah pelayanan, atau balas jasa lainnya) agar masyarakat menanamkan dananya dalam bentuk simpanan seperti giro, tabungan, sertifikat deposito, dan deposito berjangka (Kasmir, 2014). Selanjutnya bank memutar kembali dana dalam bentuk simpanan dari masyarakat atau menjual kembali dana tersebut dalam bentuk pinjaman atau yang disebut juga dengan istilah kredit atau lending. Pemberian kredit juga dikenakan beberapa ketentuan jasa pinjaman kepada nasabah (debitur) dalam bentuk bunga dan biaya administrasi. Sebagai badan usaha yang menghimpun dana dari masyarakat dan menyalurkan dana yang turut mendorong taraf hidup masyarakat dimana dalam menyalurkan dananya, Bank mengeluarkan bentuk kredit modal usaha untuk masyarakat.

Undang-Undang Perbankan Nomor 10 Tahun 1998 menjelaskan bahwa kredit adalah penyediaan uang atau tagihan yang dapat dipersamakan dengan itu, berdasarkan persetujuan atau kesepakatan pinjam meminjam antara bank dengan pihak lain yang mewajibkan pihak peminjam melunasi utangnya setelah jangka waktu tertentu dengan pemberian bunga. Dari pengertian ini dijelaskan bahwa bank sebagai penyedia dana kredit yang digunakan oleh pihak penerima kredit (debitur) untuk membiayai keperluannya. Dalam memberikan pembiayaan ini terdapat perjanjian yang mencangkup hak dan kewajiban dari kedua pihak, baik jangka waktu dan besarnya bunga serta 
sanksi apabila terjadi ingkar janji atas perjanjian yang telah disepakati bersama. Kredit atau "credere" dalam bahasa Yunani yang berarti percaya (Kasmir, 2014), menandakan pemberi kredit menaruh kepercayaan kepada penerima kredit bahwa dana yang disalurkan akan dikembalikan sesuai dengan waktu dan ketetapan yang sudah disepakati bersama. Dalam pemberian kredit ini, bank pasti akan melakukan analisis kredit mengenai latar belakang dari debitur atau nasabah mulai dari usaha yang dijalankan oleh debitur, jaminan yang diberikan dan faktor-faktor lainnya yang mempengaruhi penyaluran kredit tersebut. Tentu saja analisis ini dilakukan agar bank sebagai penyalur dana dapat yakin terhadap nasabah bahwa kredit yang diberikan benar-benar aman. Dalam penelitian ini digunakan bank milik pemerintah atau bank BUMN karena bank BUMN menyalurkan kredit usaha yang cukup besar.

Analisis kredit penting dilakukan dalam pemberian kredit dimana tidak semua kredit yang disalurkan oleh Bank terbebas dari risiko kredit. Bank yang menghadapi risiko kredit yaitu kondisi dimana debiturnya mengalami gagal bayar (Muharam, 2012). Semakin layak atau berkualitas kredit yang diberikan maka akan memperkecil kemungkinan risiko kredit yang mengindikasikan masalah. Rasio dalam pengukuran kemampuan bank dalam mengatasi risiko gagal bayar yaitu dengan rasio NonPerforming Loan (NPL). Barus \& Erick, (2016) menjelaskan terdapat 3 faktor yang mempengaruhi rasio NPL yaitu faktor internal Bank (berupa rasio Capital Adequacy Ratio, Loan to Deposit Ratio, Net Interest Margin, dan Biaya Operasional), faktor internal debitur, dan faktor eksternal non Bank dan debitur (berupa tingkat suku bunga SBI, inflasi, dan ukuran perusahaan). Penelitian terdahulu yang dilakukan oleh Barus \& Erick, (2016) mengenai analisis faktor-faktor yang mempengaruhi NonPerforming Loan pada Bank Umum di Indonesia menyatakan bahwa secara simultan CAR, LDR dan variabel lainnya mempengaruhi tingkat kredit macet namun secara parsial nilai CAR tidak berpengaruh signifikan terhadap nilai NPL. Penelitian selanjutnya oleh Agustiningrum, (2013) mengenai pengaruh CAR, LDR, dan NPL terhadap ROA (profitabilitas) pada perusahaan perbankan memberikan hasil yaitu NPLmemiliki pengaruh negatif signifikan terhadap rasio ROA.

Tujuan dari penelitian ini adalah mengetahui pengaruh Return On Asset (ROA),
Capital Adequacy Ratio (CAR), Loan To Deposit Ratio (LDR) terhadap tingkat kredit macet atau Non-Performing Loan (NPL) pada perusahaan perbankan BUMN. Diharapkan dengan adanya penelitian ini dapat memberikan pertimbangan dalam pembuatan kebijakan dalam meminimalkan risiko kredit sehingga dapat meningkatkan kemampuan manajemen perbankan sebagai fungsinya intermediasi.

\section{METODE PENELITIAN}

Penelitian ini menggunakan metode penelitian deskriptif dengan menggunakan data kuantitatif. Sugiyono, (2017) menjelaskan penelitian deskriptif berfungsi untuk mendiskripsikan atau memberikan gambaran tehadap suatu objek yang diteliti dari data sampel atau populasi sebagaimana adanya tanpa membuaat kesimpulan yang berlaku unntuk umum. Jenis data yang digunakan yaitu data kuantitatif dengan pengumpulan data purposive sampling data bank BUMN yang terdaftar di Bursa Efek Indonesia sampel diantaranya BNI, BRI, BTN dan Bank Mandiri dengan periode 2017-2019.

Metode analisis yang digunakan pada penelitian ini adalah analisis regresi linier berganda dengan menggunakan software SPSS versi 20. model regresi linier berganda antara variabel dependen dengan variabel independen dirumuskan sebagai berikut:

$$
\mathrm{NPL}=\beta \_0+\beta \_1 \mathrm{ROA}+\beta \_2 \mathrm{CAR}+\beta \_3 \mathrm{LDR}
$$

Dimana

$$
\begin{array}{ll}
\mathrm{Y} & =\text { Non-Performing Loan (NPL) } \\
\mathrm{X} 1 & =\text { Return On Asset (ROA) } \\
\mathrm{X} 2 & =\text { Capital Adequacy Ratio (CAR) } \\
\mathrm{X} 3 & =\text { Loan to Deposit Ratio (LDR) }
\end{array}
$$

\section{A. KAJIAN TEORITIS}

\section{Return On Asset (ROA)}

Return On Asset (ROA) merupakan rasio untuk mengukur kemampuan perusahaan dalam menghasilkan laba bersih dari aset yang dimiliki sekaligus mengukur tingkat pengembalian atas investasi perusahaan (Sukamulja, 2019). Perhitungan ROA dirumuskan sebagai berikut: 
ROA $=($ Laba Bersih $) /($ Total Aset $) \times 100 \%$

ROA menjadi salah satu alat pengukuran profitabilitas bank dimana tingkat ROA mencerminkan kemampuan bank dalam mengelola asetnya sehingga menghasilkan suatu keuntungan. Bank Indonesia menetapkan nilai ROA sebesar 1,5 persen. Penelitian yang dilakukan oleh Sukarno \& Syaichu, (2006) menyatakan bahwa hubungan antara ROA dengan NPL tidak signifikan dimana ROA sebagai salah satu rasio yang mencerminkan kemampuan meningkatkan laba perusahaan dari segi profitabilitasnya. Sedangkan NPL mencerminkan salah satu bentuk dari kredit yang mengalami permasalahan. Bank yang hanya berfokus pada perolehan penghasilan dari pemberian kredit sedangkan earning asset dari usaha lainnya juga memiliki prospek yang baik seperti deposito dan surat berharga lainnya juga menambah beban permasalahan yang dihadapi oleh bank tersebut.

2. Capital Adequacy Ratio (CAR)

Barus \& Erick, (2016)menyatakan Capital Adequacy Ratio (CAR) merupakan rasio kecukupan modal yang memiliki fungsi sebagai penampung risiko kerugian yang mungkin akan dihadapi oleh bank. Semakin tinggi rasio CAR yang dihasilkan maka semakin baik kemampuan bank yang bersangkutan dalam menanggung risiko kredit. Untuk menghitung rasio CAR digunakan rumus sebagai berikut:

\section{$\mathrm{CAR}=$ Modal $/ \mathrm{ATMR} \times 100 \%$}

Perbandingan rasio modal tehadap aktiva tertimbang menurut risiko (ATMR) menghasilkan rasio nilai Capital Adequacy Ratio (CAR), ketentuan pemerintah mengenai rasio CAR minimal sebesar 8 persen hingga tingkat 14 persen (Komisioner \& Jasa, 2015). Penelitian yang dilakukan oleh Adisaputra, (2012) menunjukan adanya pengaruh positif antara rasio CAR dengan NPL sejalan dengan pernyataan dimana semakin tinggi nilai CAR yang dihasilkan maka nilai dari NPL menurun dan berlaku sebaliknya.

3. Loan to Deposit Ratio (LDR)

Loan to Deposit Ratio (LDR) merupakan rasio kredit yang diberikan kepada pihak ketiga dalam Rupiah dan valuta asing, tidak termasuk kredit kepada bank lain dan dana antar bank (Bank Indonesia, 2013). Sofyan, (2016) menjelaskan LDR merupakan rasio untuk mengukur kemampuan bank dalam memenuhi kewajiban yang harus dipenuhi. Semakin tinggi tingkat LDR yang dihasilkan maka laba bank tersebut meningkat (diasumsikan bank tersebut mampu menyalurkan kredit dengan efektif) atau semakin banyak dana kredit yang dikeluarkan maka semakin tinggi rasio LDR memungkinkan terjadinya kredit macet yang semakin tinggi pula. Perhitungan untuk rasio LDR dirumuskan sebagai berikut:

LDR $=($ Total Kredit $) /($ Dana Pihak Ketiga $)$ $\times 100 \%$

Bank Indonesia menetapkan standar tingkat LDR sebesar 85\% hingga 110\%, jika bank memiliki nilai LDR yang terlalu tinggi maupun terlalu rendah maka bank terindikasi akan sulit untuk meningkatkan labanya terutama untuk pengelolaan kredit. Rasio LDR mencerminkan tingkat likuiditas bank yang mencerminkan kemampuan bank dalam membayar kewajibannya yang harus segera terpenuhi. Penelitian yang dilakukan oleh Fitria \& Linda, (2012) menyatakan bahwa adanya keterkaitan antara rasio LDR dengan NPL yang ditunjukan dengan nilai koefisien dari analisis regresi sederhana yang dilakukan olah peneliti, dimana setian perubahan $1 \%$ dari tingkat NPL akan menyebabkan penurunan tingkat LDR.

4. Non-Performing Loan (NPL) 
Non-Performing Loan (NPL) merupakan salah satu risiko yang dihadapi oleh bank yang mencerminkan tingkat risiko kredit. NPL adalah suatu rasio yang membandingkan antara total kredit bermasalah terhadap total kredit yang disalurkan kepada nasabah. Rasio ini menjadi salah satu indikator pernilaian tingkat kredit bermasalah, semakin tinggi tingkat rasio NPL yang dihasilkan maka semakin besar risiko kredit yang ditanggung oleh bank dan sebaliknya. Perhitungan rasio kredit macet (NPL) dirumuskan sebagai berikut:

NPL $=($ Total Kredit Bermasalah $) /($ Total Kredit $) \times 100 \%$

Besarnya standar NPL yang diperbolehkan oleh Bank Indonesia maksimal 5 persen (Bank Indonesia, 2015).

\section{B. KERANGKA PEMIKIRAN}

Berdasarkan tujuan penelitian dan kajian teoritis diatas, maka disusun kerangka pemikitaran sebagai berikut:

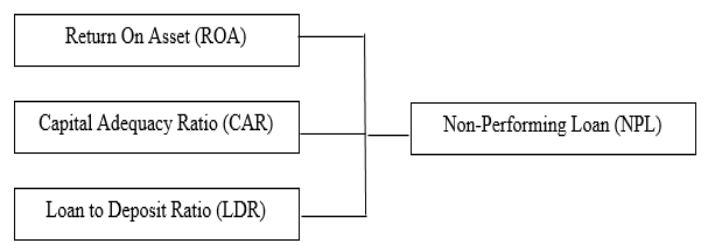

Sumber: Diolah pribadi

Dari kerangka di atas, hipotesis yang akan diuji adalah adanya pengaruh rasio Return On Asset (ROA), Capital Adequacy Ratio (CAR), Loan to Deposit Ratio (LDR) terhadap rasio kredit macet atau Non-Performing Loan (NPL) pada perusahaan perbankan BUMN di Indonesia. Variabel dependen pada penelitian ini yaitu rasio Non-Performing Loan (NPL), sedangkan variabel independennya ialah rasio Return On Asset (ROA), Capital Adequacy Ratio (CAR), Loan to Deposit Ratio (LDR).

\section{HASIL DAN PEMBAHASAN}

Analisis penelitian ini dari model regresi linier berganda diinterpretasikan menggunakan Uji Statistik.

a. Uji Asumsi Klasik

Uji Normalitas

Dikatakan model regresi berdistribusi normal jika nilai probabilitas Kolmogorov Smirnov lebih besar dari nilai signifikansinya $\alpha=5 \%$.

One-Sample Kolmogorov-Smirnov Test

\begin{tabular}{|ll|r|}
\hline & & $\begin{array}{c}\text { Unstandardized } \\
\text { Residual }\end{array}$ \\
\hline $\mathrm{N}$ & Mean & 12 \\
Normal & Std. & E-7 \\
Parameters & Deviation &, 20274912 \\
& Absolute &, 141 \\
Most Extreme & Positive &, 141 \\
Differences & Negative &,- 095 \\
Kolmogorov-Smirnov Z &, 488 \\
Asymp. Sig. (2-tailed) &, 971 \\
\hline
\end{tabular}

a. Test distribution is Normal.

b. Calculated from data.

Berdasarkan hasil perhitungan dapat diketahui bahwa nilai probabilitas Kolmogorov Smirnov yang dihasilkan sebesar 0,971 maka dengan probabilitas sebesar 0,971 lebih besar dari tingkat signifikasnsi yang digunakan yaitu $\alpha=5 \%$ dapat disimpulkan bahwa residual model regresi berdistribusi normal.

Uji Multikolinearitas

Tidak terjadi multikoleniaritas jika nilai Tolerance > 0,100 dan nilai VIF < 10,00 .

Coefficients $^{\mathrm{a}}$

\begin{tabular}{|l|r|r|r|r|}
\hline Model & \multicolumn{2}{|c|}{$\begin{array}{c}\text { Unstandardized } \\
\text { Coefficients }\end{array}$} & \multicolumn{2}{|c|}{$\begin{array}{c}\text { Collinearity } \\
\text { Statistics }\end{array}$} \\
\cline { 2 - 5 } & \multicolumn{1}{c|}{ B } & $\begin{array}{c}\text { Std. } \\
\text { Error }\end{array}$ & Tolerance & VIF \\
\hline (Constant) &,- 595 & 1,913 & & \\
ROA &,- 704 &, 206 &, 109 & 9,205 \\
CAR &, 138 &, 073 &, 277 & 3,615 \\
LDR &, 009 &, 018 &, 215 & 4,651 \\
\hline
\end{tabular}

a. Dependent Variable: NPL 
Dengan nilai VIF dari ketiga variabel tersebut tidak ada yang lebih besar dari 10, maka dapat dikatakan bahwa tidak terjadi multikolinearitas pada ketiga variabel bebas tersebut.

\section{Uji Heteroskedastisitas}

Pengujian Heteroskedastisitas digunakan untuk menguji apakah dalam model regresi penelitian terjadi ketidak samaan varians dari residual satu pengamatan ke pengamatan lainnya. Model dikatakan tidak heteroskedastisitas apabila nilai signifikansi variabelnya lebih besar dari $\alpha=5 \%$.

\section{Coefficients $^{\mathrm{a}}$}

\begin{tabular}{|c|c|c|c|c|c|}
\hline \multirow[t]{2}{*}{ Model } & \multicolumn{2}{|c|}{$\begin{array}{l}\text { Unstandardized } \\
\text { Coefficients }\end{array}$} & \multirow{2}{*}{\begin{tabular}{|c|}
$\begin{array}{c}\text { Standardized } \\
\text { Coefficients }\end{array}$ \\
Beta \\
\end{tabular}} & \multirow[t]{2}{*}{$\mathrm{t}$} & \multirow[t]{2}{*}{ Sig. } \\
\hline & B & $\begin{array}{l}\text { Std. } \\
\text { Error }\end{array}$ & & & \\
\hline (Constant) & $-1,430$ &, 830 & & 1724 &, 123 \\
\hline $1 \mathrm{ROA}$ & ,098 & ,089 & ,947 & 1,092 & ,307 \\
\hline CAR & ,010 & ,032 &, 164 & ,302 &, 770 \\
\hline LDR & ,012 & ,008 & ,955 & 1,550 &, 160 \\
\hline
\end{tabular}

a. Dependent Variable: RES2

Dengan nilai probabilitas masingmasing variabel lebih besar dari tingkat signifikansi yang digunakan yaitu $\alpha=5 \%$ maka dapat disimpulkan bahwa model terbebas dari heteroskedastisitas atau dengan kata lain bahwa model regresi memiliki varian residual tetap (homokedastisitas, hal ini juga dapat ditunjukan oleh gambar scatterplot.

\section{Uji Autokorelasi}

Dikatakan tidak ada gejala autokorelasi jika nilai Durbin Watson terletak antara du 2 sampai dengan du 4.
Model Summary ${ }^{b}$

\begin{tabular}{|l|c|r|r|r|r|}
\hline Model & $\mathrm{R}$ & $\begin{array}{c}\mathrm{R} \\
\text { Square }\end{array}$ & $\begin{array}{c}\text { Adjusted } \\
\mathrm{R} \\
\text { Square }\end{array}$ & $\begin{array}{c}\text { Std. } \\
\text { Error of } \\
\text { the } \\
\text { Estimate }\end{array}$ & $\begin{array}{l}\text { Durbin- } \\
\text { Watson }\end{array}$ \\
\hline 1 &, $951^{\mathrm{a}}$ &, 904 &, 868 &, 23774 & 1,135 \\
\hline
\end{tabular}

a. Predictors: (Constant), LDR, CAR, ROA

b. Dependent Variable: NPL

Berdasarkan perhitungan nilai du dari tabel distribusi Durbin Watson sehingga diketahui nilai probabilitasnya sebesar 2,865 (didapatkan dari 4-du) yang terletak antara $2 \mathrm{du}$ dan $4 \mathrm{du}$, maka dapat disimpulkan bahwa tidak terdapat autokorelasi antar residual pada model regresi.

b. Uji Statistik

Koefisien Determinasi

Dari hasil regresi linier berganda yang dilakukan memperoleh nilai AdjustedR2 sebesar 0,868 yang berarti bahwa variabel $\mathrm{Y}$ dapat dijelaskan oleh variabel $\mathrm{X} 1, \mathrm{X} 2, \mathrm{X} 3$ sebesar $86,8 \%$ dan sisanya sebesar $13,2 \%$ dijelaskan oleh variabel-variabel lain diluar model regresi.

\section{Model Regresi}

Pengujian ini dilakukan dengan cara membandingkan antara F-hitung dengan Ftabel.

ANOVA ${ }^{\mathrm{a}}$

\begin{tabular}{|l|r|r|r|c|c|}
\hline Model & $\begin{array}{r}\text { Sum of } \\
\text { Squares }\end{array}$ & df & $\begin{array}{c}\text { Mean } \\
\text { Square }\end{array}$ & F & Sig. \\
\hline Regression & 4,260 & 3 & 1,420 & 25,122 &, $000^{\mathrm{b}}$ \\
1 Residual &, 452 & 8 &, 057 & & \\
Total & 4,712 & 11 & & & \\
\hline
\end{tabular}

a. Dependent Variable: NPL

b. Predictors: (Constant), LDR, CAR, ROA

Berdasarkan hasil estimasi didapatkan nilai F-hitung sebesar 25,122 lebih besar dari nilai F-tabel sebesar 4,07 dan nilai probabilitas F-hitung 0,000 lebih kecil daro $\alpha=0,05$ maka dapat disimpulkan bahwa variabel $\mathrm{X} 1, \mathrm{X} 2, \mathrm{X} 3$ secara bersama-sama (simultan) berpengaruh terhadap variabel $\mathrm{Y}$ pada 
penelitian mengetahui pengaruh Return On Asset (ROA), Capital Adequacy Ratio (CAR), Loan To Deposit Ratio (LDR) terhadap tingkat kredit macet atau NonPerforming Loan (NPL) pada perusahaan perbankan BUMN. Dengan pengujian ini menunjukan goodness of fit atas model regresi, dari pengujian diatas maka disimpulkan bahwa model telah terspesifikasi dengan benar dan variabelvariabel independennya dapat memprediksi variabel dependen dengan baik.

\section{Uji Signifikansi Parsial atau Uji-t}

Pengujian ini dilakukan dengan cara membandingkan antara t-hitung dengan ttabel.

\section{Coefficients $^{\mathrm{a}}$}

\begin{tabular}{|c|c|c|c|c|c|}
\hline \multirow[t]{2}{*}{ Model } & \multicolumn{2}{|c|}{$\begin{array}{c}\text { Unstandardized } \\
\text { Coefficients }\end{array}$} & $\begin{array}{l}\text { Standardized } \\
\text { Coefficients }\end{array}$ & \multirow[t]{2}{*}{$\mathrm{t}$} & \multirow[t]{2}{*}{ Sig. } \\
\hline & B & $\begin{array}{l}\text { Std. } \\
\text { Error }\end{array}$ & Beta & & \\
\hline (Constant) &,- 595 & 1,913 & &,- 311 &, 764 \\
\hline ROA &,- 704 & ,206 & $-1,135$ & 3.415 &, 009 \\
\hline CAR & , 138 & ,073 & ,391 & 1,878 & ,097 \\
\hline LDR & ,009 &, 018 &, 118 & ,499 & ,631 \\
\hline
\end{tabular}

a. Dependent Variable: NPL

Berdasarkan hasil pengolahan pada tabel coefficients, maka persamaan regresi linear yang terbentuk adalah

Non-Performing Loan $=-0,595-$ $0,704 \mathrm{ROA}+0,138 \mathrm{CAR}+0,009 \mathrm{LDR}$

Pembahasan

1. Pengaruh ROA terhadap NPL

Berdasarkan hasil koefisien regresi Return On Asset menunjukan arah negatif, hal ini menunjukan bahwa setiap penurunan profitabilitas perusahaan perbankan (ROA) maka NPL perusahaan meningkat.

2. Pengaruh CAR terhadap NPL

Berdasarkan hasil koefisiensi regresi Capital Adequacy Ratio menunjukan arah positif namun tidak signifikan, dimana peningkatan rasio CAR mengakibatkan kenaikan rasio NPL-nya.

3. Pengaruh LDR terhadap NPL

Berdasarkan hasil koefisiensi regresi Loan to Deposit Ratio tidak berpengaruh terhadap rasio NPL.

\section{KESIMPULAN}

Dari penelitian yang dilakukan mengenai tingkat risiko gagal bayar pada bank BUMN di Indonesia, dapat diketahui bahwa tingkat profitabilitas dari rasio Retun On Asset perusahaan mempengarui tingkat risiko kredit macet (Non-Performing Loan). ROA adalah alat pengukuran profitabilitas bank dimana tingkat ROA mencerminkan kemampuan bank dalam mengelola asetnya sehingga menghasilkan suatu keuntungan. Apabila tingkat risiko kredit macet meningkat maka tingkat laba bersih dari aset perusahaan menurun. Capital Adequacy Ratio (CAR) sebagai rasio permodalan perbankan menunjukan bahwa tidak adanya pengaruh signifikan terhadap NPL. Penelitian ini bertentangan dengan penelitian yang dilakukan Lestari \& Khusnaini, (2016) yang menyatakan rasio CAR memiliki dampak positif signifikan terhadap NPL yang disebabkan oleh penambahan modal yang dilakukan principal. Begitu pula dengan rasio Loan to Deposit Ratio (LDR) oleh perbankan BUMN yang menunjukan tingkat likuiditas perusahaan perbankan yang baik sehingga tidak menimbulkan risiko kredit macet.

\section{Saran}

Dalam penelitian ini penulis menyadari bahwa masih terdapat kekurangan, untuk itu melalui penelitian ini terdapat saran bagi peneliti lain yang akan melakukan penelitian serupa sebaiknya dapat menambah faktor lainnya yang berpengaruh terhadap NPL serta periode penelitian.

\section{DAFTAR PUSTAKA}

Adisaputra, I., Manajemen, J., Ekonomi, F., \& Bisnis, D. A. N. (2012). Analisis FaktorFaktor Yang Mempengaruhi Non Performing Loan Pada Pt . Bank Mandiri ( Persero ) Tbk Lembaran Pengesahan Analisis Faktor-Faktor Yang Mempengaruhi Non Performing Loan Pada Pt . Bank Mandiri ( Persero ) Tbk. 
Agustiningrum, R. (2013). Analisis Pengaruh Car, Npl, Dan Ldr Terhadap Profitabilitas Pada Perusahaan Perbankan. E-Jurnal Manajemen Universitas Udayana, 2(8), 255030.

Bank Indonesia. (2013). Peraturan Bank Indonesia No: 15/15/PBI/2013 tentang Giro Wajib Minimum.

Bank Indonesia. (2015). Peraturan Bank Indonesia Nomor 17/11/PBI/2015 tentang Perubahan atas Peraturan Bank Indonesia Nomor 15/15/PBI/2013 tentang Giro Wajib Minimum Bank Umum dalam Rupiah dan Valuta Asing Bagi Bank Umum Konvensional. Bank Indonesia, (1), 1-5. https://doi.org/10.1007/s13398-014-01737.2

Barus, A. C., \& Erick. (2016). Analisis FaktorFaktor Yang Mempengaruhi Non Performing Loan pada Bank Umum Di Indonesia. Jurnal Wira Ekonomi Mikroskil, 6(2), 113-122. Retrieved from https://www.mikroskil.ac.id/ejurnal/index.ph $\mathrm{p} / \mathrm{jwem} /$ article/view/325

Fitria, N., \& Linda, R. S. (2012). Analisis Kebijakan Pemberian Kredit dan Pengaruh Non-Performing Loan Terhadap Loan to Deposit Ratio Pada PT. Bank Rakyat Indonesia (Persero) Tbk Cabang Rantau, Aceh Tamiang (Periode 2007-2011). Ekonomi Dan Keuangan, 1(1), 88. https://doi.org/10.1094/PDIS-08-16-1092PDN

http://kur.ekon.go.id/suku-bunga-kur-tahun2018-turun-menjadi-sebesar-7

https://www.cnbcindonesia.com/news/20191112 144500-4-114631/kredit-usaha-rakyattembus-rp-116-t-npl-123

Komisioner, D., \& Jasa, O. (2015). Otoritas jasa keuangan republik indonesia.

Kasmir. (2014). Bank dan Lembaga Keuangan Lainnya. Jakarta: Rajawali Pers

Lestari, I., \& Khusnaini, M. (2016). Analisis Faktor-Faktor Yang Mempengaruhi Non Performing Loan Pada PT. Bank Negara Indonesia (Persero) Tbk. Periode 20082015.

Muharam, H. (2012). Model risiko kredit: pendekatan dan faktor-faktor yang mempengaruhinya. Ekonomika Dan Bisnis, $1-11$.

Sofyan, M. (2016). Pengaruh Suku Bunga Kredit Modal Kerja, Capital Adequacy Ratio dan Loan to Deposit Ratio terhadap Kredit
Modal Kerja Bank Perkreditan Rakyat (Studi Kasus Pada BPR Di Kabupaten Provinsi Jawa Timur Tahun 2010-2015). Jurnal Ekonomika, 9(2), 131-137.

Sukarno, K. W., \& Syaichu, M. (2006). Analisis Faktor-Faktor Yang Mempengaruhi Kinerja Keuangan Bank Umum di Indonesia. Jurnal Studi Manajemen \& Organisasi Undip, 3(2), 46. https://doi.org/10.30659/jai.2.2.131-145

Sugiyono. (2017). Statistika Untuk Penelitian. Bandung: Alfabeta 